\title{
Thirty Years of Weather Change and Effects on a Grassland in the Peloncillo Mountains, New Mexico
}

\section{By William H. Moir}

I $\mathrm{n}$ this paper I describe and compare grassland changes since 1977 at the Central Peloncillo Research Natural Area (CPRNA) with temperature and precipitation data from its nearby weather station. The grama grasslands there have thrived through two distinctive climate periods since 1977 . The current period began with warm and dry years beginning around 1993 and continuing to the present. The cover, frequency, and diversity of herbs and shrubs in this grasslands have been precisely measured from permanently marked transects in 1977, 1984, 1996, 2002, and 2007. The grasslands flourish despite year-to-year and seasonal weather fluctuations. Because grasslands in the Southwest are so variable, the dynamics of this grassland cannot be generalized elsewhere, nor is their future maintenance a certainty; but there are reports of long-term, persisting "relict" or "recovered" grasslands without management intervention in from other locations in southern New Mexico, Arizona, and western Texas.

\section{Introduction}

It is well known that plant productivity in grasslands is affected by weather patterns. Yearly precipitation is often singled out to predict annual biomass yields. However, most reports from grasslands in the Southwest also conclude that effects of precipitation are modified by management practices such as wildlife or livestock grazing, fire regulation, range restoration, control of invasive herbaceous or woody plants, and reduction of soil compaction or erosion. ${ }^{1-5} \mathrm{I}$ first described the grama steppe and its environment in $1979 .{ }^{\circ}$ New information and advances in rangeland ecosystem knowledge prompted this report describing vegetation responses to weather patterns along with collateral observations of some of the factors affecting grassland vitality and maintenance.

Using data from a weather station established in 1977 near the grama grassland, I describe an interval of wet, cool years changing to a dry, warm, continuing drought. Then I describe the grama steppe, which had been measured and remeasured from 1977 to 2007 from three monitoring locations. The factors cited above have been defined, controlled, or measured for at least 30 years. In addition, the soil studies, grazing practices, lack of wild or prescribed fires, and plant diversity of the grassland present an argumentfor this example, at least - as to why this particular grassland is more-or-less resilient and without clear overall trends to varying precipitation and temperature regimes over the three decades. The data also show, even with these other factors accounted for at some gross level, that weather changes and vegetation response remain unclear in detail. Perennial grasses appear and disappear, increase or decrease, or have abrupt peaks. Shrubs come and go-or keep out. Senescent grass clumps are common in some years but are replaced entirely with vigorous clumps by 2007. Despite its apparent resilience, there is otherwise no overall striking or trendy response of this grassland to the two very distinctive climatic episodes. But, as I will conclude, some common or popular ideas about grassland management do not apply. This example stands at a threshold of climatic and biotic uncertainty, and there is no prevailing or compelling management truth about what works best for preserve or wildlife managers or ranchers of the Malpais Borderlands. ${ }^{7,8}$

\section{The Grama Steppe Grassland}

The grassland is a grama steppe at the Bioresearch Ranch in the Peloncillo Mountains, Hidalgo County, New Mexico (transect 16 is at lat $31^{\circ} 43^{\prime} 54.2^{\prime \prime} \mathrm{N}$, long $108^{\circ} 58^{\prime} 53.2^{\prime \prime} \mathrm{W}$ ), managed as a research natural area. ${ }^{9}$ The vegetation satisfies descriptions of desert grassland ${ }^{10}$ but lacks key plants of desert affinity or desert-grassland transition such as creosote bush (Larrea tridentata). The elevation of the grassland at $1,570-1,720 \mathrm{~m}(5,150-5,650$ feet $)$ places it well above grasslands that border Sonoran or Chihuahuan deserts. 


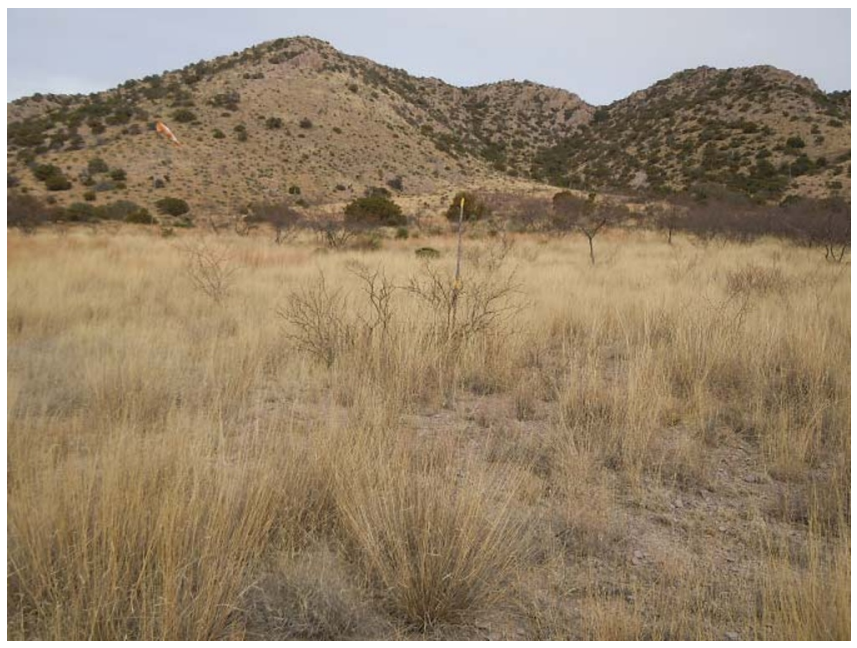

Grama steppe at Central Peloncillo Research Natural Area near transect 16, January 2011. The stick at white-thorn acacia (Acacia constricta) is banded at 1 and $2 \mathrm{~m}$ above the soil surface. This shrub is more dense and taller in the right background near the southeastern edge of the alluvial fan where soil erosion occurred.

The rhyolitic landform of this grama steppe is an intracanyon alluviul fan apparently deposited in the late Holocene. ${ }^{11}$ The fan is mostly inactive as an alluvial deposit because entrenched washes divert runoff from adjoining slopes that might otherwise braid its surface, create rills, or cause sheet erosion. ${ }^{12}$ The gravelly, coarse-loamy texture of the deep soils (Aridic Haplustolls on the upper fan, Typic Haplustolls on the lower fan) are, in effect, sponges soaking up on-site precipitation. The exception is the southeastern edge of the fan at its lower elevation. An erosion slope is characterized by rills and small gullies, a cobbly and uneven soil surface, and a dominant population of shrubs, mostly established before 1972 .

Livestock grazing on the grama steppe had a long but undocumented history specific to this study area. ${ }^{6}$ However, all livestock were withdrawn in 1972, and except for occasional but inconsequential trespass cattle, there has been no herd grazing since. No wild or prescribed fire has been known to have taken place at least for 100 years and probably even longer (Bill Miller, Sr., private oral communication to the author in 1974).

\section{Methods}

\section{Weather}

In August 1977, the National Weather Service cooperative weather station at Rodeo, New Mexico, was discontinued. The instrument shelter, $\mathrm{min} / \mathrm{max}$ thermometer, and six-inch rain gauge were reestablished at the Bioresearch Ranch. National Weather Service protocols for daily reading and recording temperature and precipitation began at that time. The station was located at $1,575 \mathrm{~m}(5,170$ feet $)$ elevation in an emory oak savanna, about $300 \mathrm{~m}$ (1,000 feet) from the center of the grama steppe tract.
Before 1988, there were months in which daily readings were missed. When five or fewer days were missed, monthly summaries were adequate, if not exact, given the accumulative nature of the instruments. If more than five days were missed, then the month's temperatures become approximate, depending on how many days and how long the missing periods extended. Total monthly precipitation might be affected, but less so because the bucket stores water from previous events, until emptied. Most months over the 30-year period had no missing days, and about a dozen had only one or two missed daily recordings.

\section{Vegetation}

I measured vegetation using canopy coverage from three permanent transects initially established to measure soil erosion., ${ }^{4,13,14}$ Transects 14 and 15 were at the upper third of the alluvial fan and transect 16 near the lower edge. Each transect was $30 \mathrm{~m}$ in length. Canopy cover for each species was measured in $2 \times 5 \mathrm{dm}$ quadrats spaced at $1 \mathrm{~m}$ intervals. Cover of each species was averaged from the 30 quadrat frames in each transect. Plant vouchers were collected and deposited at various herbaria. ${ }^{15}$ I report measurements from August to early October in 1977, 1984, 1996, 2002, and 2007. Because there were only three transect samples in the grama steppe and only five years monitored (totaling 12 sample years), statistical trends or other comparisons were not made. However, when combined with seven other transects in other grasslands of the Bioresearch Ranch, I report relevant statistical results computed by John A. Ludwig. ${ }^{12}$

Plant diversity over the entire grama steppe was gradually accumulated from plants collected over the years by various botanists. I made collateral observations of termite activity in each quadrat in 2002, a wet summer, and in all years made notes of foliage clipped by wildlife and qualitative observations

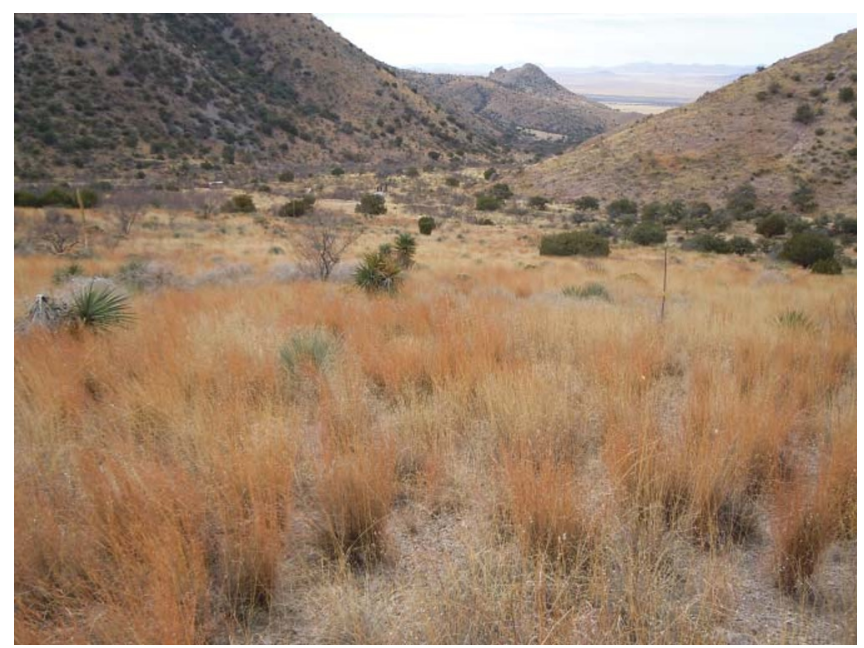

Grama steppe looking downslope from alluvual fan in upper Post Office Canyon at the Bioresearch Ranch, January 2011. The stick at the end of transect 15 is banded at $1 \mathrm{~m}$ and $2 \mathrm{~m}$ above ground. The reddish grass is Texas bluestem (Schizachyrium cirratum). 


\begin{tabular}{|c|c|c|c|}
\hline Years & Mean & Std dev. & $t^{*}$ \\
\hline \multicolumn{4}{|l|}{ Temp. ( $\left.{ }^{\circ} \mathrm{F}\right)$} \\
\hline 1978-1992 & 58.0 & 0.7 & \\
\hline $1993-2007$ & 60.6 & 1.0 & 0.00 \\
\hline \multicolumn{4}{|l|}{ Precip. (inches) } \\
\hline 1978-1992 & 20.1 & 3.7 & \\
\hline $1993-2007$ & 15.2 & 3.4 & 0.00 \\
\hline \multicolumn{4}{|c|}{ July-Sept. (monsoon) } \\
\hline 1978-1992 & 3.1 & 1.8 & \\
\hline $1993-2007$ & 2.5 & 1.4 & 0.07 \\
\hline
\end{tabular}

of fecal pellets of lagomorphs, deer, and otherwise unidentified small mammals.

\section{Results}

\section{Weather Patterns}

The climate summary of research natural area (Table 1) reveals two climatic periods. A two-sample, equal variance Student's $t$ test indicated that mean annual temperature (MAT), total annual precipitation (TAP), and summer (monsoonal) rainfall were significantly different in each period. The first period, 1978 to 1992, was relatively wet and cool. A warming trend began in $1987\left(\mathrm{MAT}=56.7^{\circ} \mathrm{F}\right.$ ) and carried into the second period of warm and dry years from 1993 to 2007. Within this period a record low TAP of 9.0 inches/year occurred in 2003 and a high year of 23.5 inches/year in 1997. Except for that high year, most other years were well below the TAPs of the first period. A cool year $\left(58.2^{\circ} \mathrm{F}\right)$ in 1998 was the only year dipping to the levels of period 1 . The warmest of the 30 years were 1994 and 2002, both with MATs at nearly $62^{\circ} \mathrm{F}$. Long heat waves occurred 24 June-16 July 1994, and again 14 June-20 July 2005 , both with average daily maximum temperatures of $97.5^{\circ} \mathrm{F}$ and numerous, consecutive days over $100^{\circ} \mathrm{F}$.

\section{Vegetation}

Consider 1977 as a threshold year. That year established a baseline of cover-whatever the history of vegetation cover dynamics during previous years and whatever were the climatic and other environmental influences that influenced the baseline before 1977 (Tables 2 and 3). From that threshold, vegetation entered the cool-wet period (sampled in 1984 ) and then the warm-dry period (sampled in 1996, 2002, 2007). The year 2007 saw an average decline (26\%) in total vegetation cover from 1977. But there was no overall trend in vegetation change during the 30 years. For example, at transects 14 and 15 total cover was about the same in 2002 (a wet summer) as in 1977. Overall, total vascular plant cover ranged from $14 \%$ to $78 \%$ over the 12 transect year measurements. Perennial grasses ranged from $47 \%$ to $93 \%$ of the total cover, and woody shrubs from $4 \%$ to $43 \%$ of the total cover. But various components of vegetation exhibited differing responses over the two climatic periods.

Grasses. From the baseline year nearly all grasses greatly declined in cover in 1984, a year within the wet-cool period. I offer no explanation for this counterintuitive decline, but see the work of Ludwig et al. ${ }^{4}$ for similar results at Otero Mesa, New Mexico. By 2007 total grass cover had not reached its average threshold total of 51\%. The first impression is that grass cover never recovered its high threshold level; but, given the high variability of cover from year to year and place to place, that impression can be misleading. For example, in each transect there were grass species that exceeded or about equaled their 1977 cover in one or another subsequent monitoring year. Rather than a trend or real decline of grasses there may be a kind of persistence with ups and downs. These responses, including apparent declines in some monitoring years, seemed affected mostly by seasonal precipitation patterns of the monitoring year and the year before (I cannot analyze this rigorously on sparse data).

The diversity of grasses (Tables 2 and 3), each responding differently to the 30-year climate variations, may help explain the fluctuating persistence of native grasses through a drought. ${ }^{16}$ The leading dominant grass, side-oats grama (Bouteloua curtipendula), was reduced to approximately half its cover in 1977. If I include the other grassland monitoring sites at the Bioresearch Ranch into the analysis, the decline by 1996 was significant at the $5 \%$ probability level. ${ }^{12}$ However, side-oats grama did not significantly decline at Santa Rita grasslands in southeastern Arizona during the drought years that followed. ${ }^{17}$

I could not analyze the following grasses statistically since they occurred in so few transects. Hairy grama (Bouteloua hirsuta) fluctuated sharply and nearly disappeared in all transects. Texas bluestem (Schizachyrium cirratum) more or less increased (transects 14 and 15). The cover of blue grama (Bouteloua gracilis, transect 16) remained about the same in 2002 and 2007 as 1977. Tanglehead (Heteropogon contortus) did not occur in transects in 1977, attained 7\% cover in transect 15 in 1996, and disappeared from transects altogether by 2007 (it remains in the steppe). Cane bluestem (Bothriochloa barbinodis) had peaks in the baseline year but was generally minor thereafter, although not disappearing. Black grama (Bouteloua eriopoda), restricted to Typic Haplustolls of transect 16, consistently declined, another counterintuitive result since this is a grass more prevalent at lower elevations (and thus drier, hotter grasslands). Nevertheless, this grass declined as well at the Santa Rita Range. ${ }^{17}$ Lehmann lovegrass (Eragrostis lebmanniana) was merely present in the grama steppe but was not found within three meters of any 


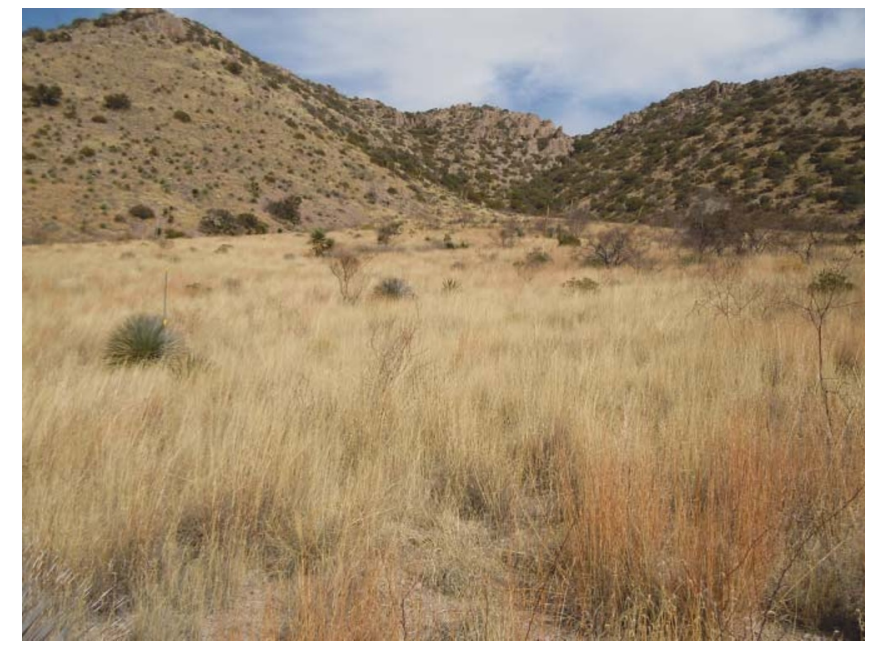

Grama steppe on alluvial fan at the Bioresearch Ranch, upper Post Office Canyon, January 2011. The reddish grass is Texas bluestem (Schizachyrium cirratum). The scale is near a sotol bush (Dasylirion wheeleri).

transect. It remains abundant along the road that crosses the fan near its lower elevation.

Other collateral observations seem important. Prior to 2002, many large grass clumps had dead centers, ${ }^{12}$ and there were only a few smaller clumps without dead centers. In 2007 there were no clumps with dead centers, nor any sign of senescent grasses with dead centers. In 2002 about $8 \%$ of the quadrats had termite castings in the aboveground dead foliage. Other quadrats may have had castings too, but they crumble easily and were not clearly noted. Unfortunately collateral termite observations within quadrats were not recorded in earlier years.

Woody plants. Woody plants comprised $4-43 \%$ of the total vegetation cover over the 12 transect years. Only in transect 15 was there an increase in woody plant cover in 2007 from that of 1977, due primarily to white-thorn acacia (Acacia constricta). However, including other grassland monitoring sites in analysis, the fluctuations in white-thorn acacia in 1977, 1984, and 1996 were not significant. ${ }^{12}$ In all three transects of the grama steppe the proportion of woody plants remained at about the 1977 level, and Acacia was more or less unimportant. However, this shrub does have invasive potential. The evidence for this is seen in the eroded section on a southeastern portion of the fan. Here the soil surface is laced with rills and shallow gullies, and check dams established in these gullies in the 1970s are back-filled with sediments from both local sheet erosion and more distant gully erosion. Judging from the size and longevity of large shrubs, this area (east of transect 16) has long been dominated by white-thorn acacia mostly established in the livestock grazing era before 1972. In some places the shrubs formed thickets with sparse grasses beneath.

Generally, however, there is slight evidence that woody shrubs are increasing elsewhere or replacing perennial grasses. Because of the few transects, however, only the decline of snakeweed (Gutierrezia) was significant at the $5 \%$ probability level. ${ }^{12}$ Snakeweed had only trace cover in the grama steppe transects and was included in the "other" category of Table 3. Velvet mesquite (Prosopis velutina) also declined within the steppe, and the litter remains of sotol (Dasylirion wheeleri), turpentine bush (Ericameria laricifolia), and century plant (Agave palmeri) occurred along or very near one or more transects. The occurrence of burroweed (Isocoma tenuisecta) not far from transect 16 is interesting. This low shrub is invasive and widespread in nearby livestock grazed lands and elsewhere. ${ }^{10,12}$ Individuals are common along the road through the lower elevation of the steppic fan but have not yet been found within the steppe. Similarly, turpentine bush and catclaw minosa (Mimosa aculeaticarpa var. biuncifera) are both dominant on alluvial rangelands below the fence adjoining this grama steppe. The former had much dieback throughout the region, but many shrubs whose older foliage yellowed and that otherwise displayed low vigor during the drought nevertheless recovered after good summer rains in 2002. The mimosa occurs in the above-mentioned Acacia area but is rare in the noneroded soils of the grama steppe. Only mariola (Parthenium incanum) and oreganillo bush (Aloysia wrightii) seem to be locally increasing from patches of soil churned by wildlife near transect 15 . The widespread low shrub, bastardsage (Eriogonum wrightii), seldom recovered its high cover values of 1977. Its dieback can be attributed to interactions of drought, herbaceous competition (particularly shading by overtopping grasses), and occasional browsing by deer.

Forbs. Numerous forb species (broad-leafed herbs in contrast to grasslike herbs), both annuals and perennials, are found in the grassland (Table 2) and may have episodes of local abundance during one or more years (whether or not a monitoring year). Some are "winter" forbs with greatest cover around April or early May and are thus underestimated or omitted from Table 2. Forbs are a generally insignificant in cover, except for erratic and seasonal "explosions" of annuals, such as carpet weed (Drymeria molluginea) during episodes of good winter moisture or summer rains. The lowest cover of forbs was, like the grasses, in 1984. The most common perennial each year was leatherleaf croton (Croton pottsii var. pottsii), whose cover fluctuated throughout the years without meaningful gains or losses. Perennials such as deervetch (Lotus plebius and Lotus greenei) were common at the end of the period. These are nitrogen fixers observed to be important to lagomorphs, rodents, and white-tailed deer that feed here (defoliated plants and the droppings of animals that feed on them were frequent in the transect areas and throughout the grassland). The diversity and ubiquity of forbs in all years suggests their ecological importance despite overall low coverage compared to grasses., ${ }^{2,18,19}$

\section{Factors of Grassland Maintenance Are Often Local}

Good examples of native grasslands in the Southwest are sometimes found as isolated fragments of landscapes that 
Table 2. List of plant taxa observed or collected in the grama steppe

Grasses and grasslike plants

Aristida adscensionis $L$.

Aristida divaricata Willd.

Aristida ternipes Cav. var ternipes

Aristida schiedeana var orcuttiana

Bothriochloa barbinodis (Lag.) Herter

Bouteloua curtipendula (Michx) Torr.

Bouteloua eriopoda (Torr.) Torr.

Bouteloua gracilis (Willd.) Lag. ex Griffiths

Bouteloua hirsuta Lag.

Cyperus fendlerianus Boeckl.

Digitaria californica (Benth.) Henr.

Digitaria pubiflora (Vasey ex L.H. Dewey) Wipff

Eragrostis intermedia Hitchc.

Eragrostis lehmanniana Nees.

Elyonurus barbiculmus Heck.

Heteropogon contortus (L.) Beauv. ex R\&S

Leptochloa dubia (HBK) Nees.

Lycurus phleoides Kunth

Muhlenbergia emersleyi Vasey

Panicum obtusum HBK

Schizachyrium cirratum (Hack.) Woot. \& Standley

Setaria vulpiseta (Lam.) Roem. \& Schult.

Urochloa arizonica (Schrib. \& Merr.) Morrone \& Zuloaga

Woody plants

Acacia constricta Benth

Aloysia wrightii Heller ex Abrams

Dasylirion wheeleri Wats.

Ericameria laricifolia (Gray) Shinners

Eriogonum wrightii Torr.

Gutierrezia microcephala (DC) A. Gray

Isocoma tenuisecta Greene*

Mimosa aculeaticarpa var biuncifera (Benth) Barneby

Parthenium incanum HBK

Prosopis velutina Wooton

Rhus virens Lindh. ex Gray var coriophylla (W\&S)

Senecio flaccidus var flaccidus Hack

Yucca schottii Engelm.

\section{Table 2. Continued}

Succulents

Agave palmeri Engelm.

Coryphantha scheeri var robustispina (Schott) L. Benson

Echinocereus fendleri (Engelm.) F. Seitz

Echinocereus rigidissimus (Engelm.) Haage $f$.

Mammillaria heyderi var macdougalii (Rose) L. Benson

Opuntia Mill. spp.

Cylindropuntia spinosior (Engelm. \& Bigel) Toumey

Broad-leafed herbs (forbs)

Acacia angustissima (Mill.) Kuntze

Amaranthus palmeri Wats.

Chaetopappa ericoides (Torrey) Nesom

Chamaecrista leptademia (Greenm.) Cockerell

Chamaesyce albomarginata (T\&G) Small

Chamaesyce revoluta (Engelm.) Small

Chamaesyce vermiculata (Raf.) House

Croton pottsii var pottsii (Klotz.) Muell.-Arg.

Desmanthus cooleyi (Eaton) Trel.

Drymaria molluginea (Lag.) Didr.

Erigeron nudiflorus Buckl.

Euphorbia dentata Michx.

Euphorbia bilobata Engelm.

Evolvulus sericeus Swarts

Ipomoea spp.

Lotus greenei Ottley ex Kearney \& Peebles

Lotus plebeius (Brand) Barneby

Machaeranthera scabrella (Greene) Shinners

Pectis longipes Gray

Polanisia dodecandra ssp trachysperma (T\&G) Iltis

Proboscidea parviflora (Woot.) Woot. \& Standl.

Rhynchosia senna var texana (T\&G) M. C. Johnston

Sanvitalia abertii Gray

Solanum elaeagnifolium Cav.

Stephanomeria thurberi Gray

Tetraclea coulteri Gray

Tragia ramosa Torrey

Zinnia grandiflora Nutt.

* Only on disturbed soil along road. 
Table 3. Canopy coverage (\%) by date and transect of vascular plants in the grama steppe. Subtotals are rounded to the nearest percent. Blanks indicate the plant was not sampled (or missed) in the 30 quadrat frames along each transect

\begin{tabular}{|c|c|c|c|c|c|c|c|c|c|c|c|c|c|c|}
\hline \multirow[b]{2}{*}{ Plant taxa } & \multicolumn{4}{|c|}{ Transect 14} & \multicolumn{5}{|c|}{ Transect 15} & \multicolumn{3}{|c|}{ Transect 16} & \multirow[b]{2}{*}{$\begin{array}{l}\text { Avg. } \\
(\%)\end{array}$} & \multirow[b]{2}{*}{$\begin{array}{l}\text { Const. } \\
(\%)\end{array}$} \\
\hline & $\begin{array}{l}\text { Aug. } \\
1977\end{array}$ & $\begin{array}{l}\text { Aug. } \\
1984\end{array}$ & $\begin{array}{l}\text { Sept. } \\
1996\end{array}$ & $\begin{array}{l}\text { Oct. } \\
2007\end{array}$ & $\begin{array}{l}\text { Aug. } \\
1977\end{array}$ & $\begin{array}{l}\text { Aug. } \\
1984\end{array}$ & $\begin{array}{l}\text { Sept. } \\
1996\end{array}$ & $\begin{array}{l}\text { Sept. } \\
2002\end{array}$ & $\begin{array}{l}\text { Oct. } \\
2007\end{array}$ & $\begin{array}{l}\text { Aug. } \\
1977\end{array}$ & $\begin{array}{l}\text { Sept. } \\
2002\end{array}$ & $\begin{array}{l}\text { Oct. } \\
2007\end{array}$ & & \\
\hline \multicolumn{15}{|l|}{ Graminoids } \\
\hline Bouteloua curtipendula & 27.0 & 8.9 & 2.0 & 8.7 & 32.0 & 3.2 & 3.9 & 8.4 & 13.5 & 18.0 & 11.2 & 8.2 & 12 & 100 \\
\hline Bouteloua hirsute & 18.0 & 7.2 & 34.7 & 0.1 & 11.0 & 3.5 & 10.7 & 0.5 & 0.1 & 8.0 & 0.1 & 0.0 & 8 & 100 \\
\hline Schizachyrium cirratum & 4.0 & 4.1 & 8.8 & 8.9 & 4.0 & 0.6 & 14.9 & 9.6 & 6.9 & 0.0 & 0.1 & 0.0 & 5 & 100 \\
\hline Bothriochloa barbinodis & 1.0 & 0.4 & 0.5 & 5.1 & 14.0 & 2.2 & 0.1 & 0.1 & 0.5 & 11.0 & 0.0 & 0.0 & 3 & 100 \\
\hline Aristida spp. & 0.6 & 0.4 & 0.1 & 4.1 & 3.5 & 0.1 & 0.2 & 0.7 & 0.7 & 4.3 & 2.1 & 1.1 & 1 & 100 \\
\hline Bouteloua gracilis & & & & 0.0 & 0.0 & & 0.1 & 0.1 & & 17.0 & 15.3 & 21.9 & 5 & 58 \\
\hline Urochloa arizonica & 0.1 & & 1.5 & 0.6 & & & 1.3 & 31.3 & 0.2 & & 1.0 & 1.4 & 3 & 50 \\
\hline Bouteloua eriopoda & & & & & & & & & & 7.0 & 2.0 & 0.5 & 1 & 25 \\
\hline Heteropogon contortus & & & & & & & 7.3 & 0.1 & & & & & 1 & 17 \\
\hline Other graminoids* & 0.4 & 0.2 & 0.0 & 0.0 & 0.9 & 0.0 & 0.0 & 0.0 & & 0.8 & 1.0 & 0.1 & 0 & \\
\hline Graminoids subtotal & 51 & 21 & 48 & 28 & 65 & 10 & 39 & 51 & 22 & 66 & 33 & 33 & 39 & \\
\hline \multicolumn{15}{|l|}{ Succulents* } \\
\hline Succulents subtotal & 1 & & 0 & 0 & 0 & & 0 & 0 & 0 & & 0 & 0 & 0 & \\
\hline \multicolumn{15}{|l|}{ Woody plants } \\
\hline Eriogonum wrightii & 9.0 & 3.6 & 11.5 & 1.1 & 6.0 & 3.3 & 6.0 & 1.2 & 0.6 & 3.0 & 0.0 & 0.0 & 4 & 100 \\
\hline Ericameria laricifolia & 0.0 & & 0.5 & & 0.0 & & 0.1 & 0.0 & 0.0 & 0.0 & 0.0 & & 0 & 67 \\
\hline Acacia constricta & & & & 2.2 & 0.0 & & 3.1 & 6.3 & 13.2 & & 0.0 & 0.5 & 2 & 58 \\
\hline Parthenium incanum & 0.0 & & 0.0 & 0.0 & 0.0 & & 0.0 & 1.3 & 2.1 & & & & 0 & 58 \\
\hline Aloysia wrightii & & & 0.0 & 0.5 & 0.0 & & 0.0 & 0.0 & 8.0 & & & & 1 & 50 \\
\hline Prosopis velutina & & & & & & & 0.0 & & & 0.0 & 7.3 & 1.3 & 2 & 33 \\
\hline Others* & 0.1 & & 0.0 & 0.0 & 0.0 & & 0.0 & 0.0 & 0.0 & 0.0 & 0.0 & 0.0 & 0 & \\
\hline Woody plants subtotal & 9 & 4 & 12 & 4 & 6 & 3 & 9 & 9 & 24 & 3 & 7 & 2 & 8 & \\
\hline \multicolumn{15}{|l|}{ Forbs } \\
\hline Croton pottsii var. pottsii & 10.0 & 1.5 & 1.7 & 9.1 & 6.0 & 0.4 & 4.8 & 1.7 & 4.0 & 1.0 & 9.6 & 6.6 & 5 & 100 \\
\hline Tragia ramose & 0.0 & & 0.0 & & 0.1 & 0.1 & 0.5 & 0.6 & 0.5 & 0.0 & 0.1 & 0.1 & 0 & 83 \\
\hline Lotus spp. & & & & 5.2 & 0.1 & 0.0 & 0.1 & & 5.5 & & & 0.9 & 1 & 50 \\
\hline Solanum elaeagnifolium & 0.1 & & 0.0 & 0.0 & & & & & & & 0.5 & 0.0 & 0 & 42 \\
\hline Drymaria molluginea & & & & & & & & 5.4 & & & 17.5 & 0.0 & 2 & 25 \\
\hline Others* & 0.8 & & 1.7 & 0.2 & 0.3 & 0.1 & & 1.5 & & 0.6 & 1.7 & 0.0 & 1 & \\
\hline Forbs subtotal & 11 & 2 & 3 & 15 & 7 & 1 & 5 & 9 & 10 & 2 & 29 & 8 & 8 & \\
\hline Total (all vascular plants) & 72 & 26 & 63 & 46 & 78 & 14 & 53 & 69 & 56 & 71 & 70 & 43 & 55 & \\
\hline$\%$ graminoids & 71 & 81 & 76 & 60 & 84 & 71 & 72 & 74 & 39 & 93 & 47 & 78 & 71 & \\
\hline$\%$ woody plants & 13 & 14 & 19 & 8 & 8 & 24 & 17 & 13 & 43 & 4 & 11 & 4 & 15 & \\
\hline
\end{tabular}


somehow escaped or recovered from regionwide excesses of livestock and wildlife grazing of the last 150 years. ${ }^{16}$ Such is the case in this study. Usually the floras of these fragments differ from floras described from much-published examples of grasslands at research and experimental ranges or areas withdrawn from livestock grazing such as the Jornada del Muerto, Santa Rita Experimental Range, Otero Mesa, Big Bend National Park, or the Appleton-Whitell Research Ranch. Certainly the environments and historical uses differed in all these areas and so too the ecosystem dynamics. What is to be learned from this grama steppe?

A partial answer is that sometimes very little is learned, especially if borrowed conclusions are from poorly designed studies or biases against livestock grazing practices in general. ${ }^{7}$ However, livestock management was not an issue in locating the monitoring plots. Neither "overgrazing" nor "undergrazing"- epithets usually assigned to livestock management-accounted for plant cover or vigor over the 30 years. Another partial answer is that we can learn little if the fragments are so small and isolated that their genetic complement is compromised by inbreeding, genetic drift, and strong environmental variations (stochasticity). The grama steppe is neither that small nor isolated to that degree. All the vascular plants are widely distributed at the CPRNA, on adjoining ranches, and throughout the Borderlands. I suspect that most connective routes to and from this tract are porous to local and distant movements of most plants and animals. As for environmental stochasticity, this study shows recent climatic variations, although perhaps not the extremes possible upon longer-term regional or global warming. However, it is clear from nearby soils and landforms that plant composition and structure would change rapidly should soils erode at rates faster than past geophysical erosion ${ }^{12}$ - a possible by-product of long-term climate change should weather extremes intensify.

I now turn to more concrete conclusions. It is clear that fire was not required to maintain this grama grassland from shrub invasion or to invigorate grass production. The senescent grass clumps were gone in 2007. Biomass turnover, nutrient cycling, and microsuccession were facilitated to some extent by termites ${ }^{19}$ and by large and small wildlife as herbivores.

Livestock herd grazing can be beneficial to grasslands, ${ }^{3}$ but examples of grassland maintenance without any history of domestic livestock are also reported. A grassland with minimal soil erosion, high floristic diversity, and locations never apparently grazed by domestic livestock was described from Otero Mesa, New Mexico. ${ }^{4}$ Perhaps the most similar example is Dutchwoman Butte on the Tonto National Forest, Arizona. ${ }^{13}$ That grassland, dominated by side-oats and hairy gramas and plains lovegrass (Eragrostis intermedia), occurred on noneroded, well-drained Aridic Argiustoll soils near the lower woodland region at 1,220-1,525 m $(4,000-5,000$ feet $)$ elevation. The vegetation structure and canopy cover of grasses were within the measured range of the grama steppe. According to the authors the most striking aspects of Dutchwoman Butte were the diversity, density, and vigor of the grasses. What the grama steppe and these other examples have in common are noneroded soils with minimum soil surface disturbance, high floristic diversity, few nonnative or invasive plants, and in situ processes for maintaining plant vigor.

Invasive and other plants considered "undesirable" to range managers are not advancing into the grama steppe. Perhaps white-thorn acacia is restrained only so long as soils remain uneroded. Similarly, other undesirable plants discussed above did not "invade" in either climate period. And no management action was needed to improve the grassland for whatever purpose. Along with high plant diversity the other factors in sustainability are soil stability and biomass turnover via the guts of native animals both large and small.

\section{Persistence and the Future}

In this article, I show that the grama steppe thrived from a relatively wet-cool climatic period into and through a warm, droughty period. Given the overall sensitivity of grassland ecosystems to such variability and the continuing "natural area" management of the Bioresearch Ranch, climate will continue to be the overall determinant of grassland expression from year to year. In the near future if climate variability remains in the ballpark of the figures in Table 1 , the grassland will probably look much as described here. However, grassland ecosystems have a dynamic influenced by a large degree of uncertainty. ${ }^{8}$ One cannot be complacent looking more than a few decades ahead. Distant prospects of future conditions are already expressed nearby. Most important, I feel, is the uncertainty of climate change itself, extending beyond the parameters of the last 30 years. Of course, this grassland will respond, but not in ways one might anticipate. Something might trigger a spread of white-thorn acacia, Lehmann lovegrass, burrow weed, or some unsuspected introduced plant lying in wait at the threshold. An abundance of small mammals might be attracted by future vegetation cover and plentiful food here. ${ }^{18}$ A wildfire could introduce new plants from the soil seed bank. An episode of accelerated soil erosion might be in the roll of the dice. Or we may find unforeseen effects of human activity on lands that adjoin the steppe, including land ownerships on other sides of fences where major changes of management will doubtless occur.

\section{Acknowledgments}

This study could not have been done without the long-term unwavering field, logistic, and financial support of Robert and Kathryn Scholes. I also thank the many botanical, zoological, soil, and weather station professionals who stayed with this study over so many years. Two editors from Rangelands greatly improved the manuscript. 


\section{References}

1. Воск, С. E., AND J. H. Воск. 1997. Shrub densities in relation to fire, livestock grazing, and precipitation in an Arizona desert grassland. Southwestern Naturalist 42:188-193.

2. DeBano, S. J. 2006. Effects of livestock grazing on aboveground insect communities in semi-arid grasslands of southeastern Arizona. Biology and Conservation 15:2547-2564.

3. Keppel, W. 2005. Animal impact: how trampling and disturbance benefit grassland ecosystems. Managing wholes, creating a future that works. Available at: http://www.managingwholes. com/animal-impact.htm. Accessed 12 April 2011.

4. Ludwig, J. A., E. Muldavin, and K. R. Blanche. 2000. Vegetation change and surface erosion in desert grasslands of Otero Mesa, southwestern New Mexico: 1982 to 1995. The American Midland Naturalist 144:273-285.

5. Martin, S. C. 1986. Eighty years of vegetation change on a semi-desert range in southern Arizona, U.S.A., and evaluation of causes. In: Rangelands: a resource under siege. Proceedings of the 2nd International Rangeland Conference; 13 May 1984; Adelaide, Australia. New York, NY, USA: Cambridge University Press. p. 53.

6. Moir, W. H. 1979. Soil-vegetation patterns in the central Peloncillo Mountains, New Mexico. The American Midland Naturalist 102:317-331.

7. Brown, J. H., And W. McDonald. 1995. Livestock grazing and conservation on Southwestern rangelands. Conservation Biology 9:1644-1647.

8. Peters, D. C., R. A. Pielke, B. T. Bestelmeyer, C. D. Allen, S. Munson-McGee, and K. M. Havstad. 2004. Cross-scale interactions, nonlinearities, and forecasting catastrophic events. Proceedings of the National Academy of Sciences 101(42):1513015135.

9. Peterson, R. S., and E. Rasmussen. 1986. Central Peloncillo Research Natural Area. Fort Collins, CO, USA: US Department of Agriculture Forest Service, Rocky Mountain Forest and Range Experiment Station. General Technical Report RM-136. p. 12-16.

10. McClaran, M. P., and T. R. Van Devender [eds.]. 1995. The desert grassland. Tucson, AZ, USA: University of Arizona Press. 346 p.

11. Gile, L. H. 1977. Holocene soils and soil-geomorphic relations in a semiarid region of southern New Mexico. Quaternary Research 7:112-132.
12. Moir, W. H., J. A. Ludwig, and R. T. Scholes. 2000. Soil erosion and vegetation in grasslands of the Peloncillo Mountains, New Mexico. Soil Science Society of America Journal 64:1055-1067.

13. Аmbos, N., G. Robertson, and J. Douglas. 2000. Dutchwoman Butte: a relict grassland in central Arizona. Rangelands 22:3-8.

14. Ludwig, J. A., ANd W. H. Moir. 1987. A baseline of soil erosion and vegetation monitoring in desert grasslands: Chihuahua, Texas, and New Mexico. Fort Collins, CO, USA: US Department of Agriculture Forest Service, Rocky Mountain Forest and Range Experiment Station. General Technical Report RM-150. p. 214-220.

15. Moir, W. H. 2010. Vascular plants of the Central Peloncillo Research Natural Area. Las Cruces, NM, USA: Las Cruces Area Office, USDI Bureau of Land Management. 27 p.

16. Fletcher, R., and W. A. Robbie. 2004. Historic and current conditions of southwestern grasslands. In: D. M. Finch [ED.]. Assessment of grassland ecosystem conditions in the Southwestern United States. General Technical Report RMRSGTR-135. Vol. 1. Fort Collins, CO, USA: US Department of Agriculture, Forest Service, Rocky Mountain Research Station. p. $120-129$.

17. Crimmins, M. A., and T. M. Mau-Crimmins. 2003. Climate variability and plant response at the Santa Rita Experimental Range, Arizona. In: M. P. McClaran, P. F. Ffolliott, and C. B. Edminster [tech. coords.]. Santa Rita Experimental Range: 100 years (1903 to 2003) of accomplishments and contributions: conference proceedings; 30 October-1 November 2003; Tucson, AZ, USA. Ogden, UT, USA: US Department of Agriculture Forest Service, Rocky Mountain Research Station; Proc. RMRS-P-30. 197 p.

18. Morrison, M. L., A. J. Kuenzi, C. F. Brown, and D. E. Swann. 2002. Habitat use and abundance trends of rodents in southeastern Arizona. Southwestern Naturalist 47(4):519-526.

19. Whitford, W. G., G. S. Forbes, and G. L. Kerley. 1995. Diversity, spatial variability, and functional roles of invertebrates in desert grassland ecosystems. In: M. P. McClaran and T. R. Van Devender [EDs.]. The desert grassland. Tucson, AZ, USA: University of Arizona Press. p. 152-195.

Author is Research Ecologist (retired), USDA Forest Service, Box 253, Trinidad, CA 95570, USA. 